\title{
AN EPIGENETIC ORIGIN FOR THE NEW SCHEELITE AND WOLFRAMITE OCCURRENCES IN THE MIDDLE JEQUITINHONHA VALLEY, MINAS GERAIS, BRAZIL
}

\author{
RUI L.B.P. MONTEIRO*, OTHON H. LEONARDOS** and JOSÉ MARQUES CORREI A-NEVES*
}

\begin{abstract}
RESUMO UMA ORIGEM EPIGENÉTICA PARA AS NQVAS OCORRÊNCIAS DE SCHEELITA E VOLFRAMITA, NO MÉDIO VALE DO JEQUITINHONHA; MINAS GERAIS, BRASIL. Dois tipos de mineralizações foram reconhecidas no Médio Vale do Jequitínhonha (MJV): 1. scheelita associada com níveis cálcio-silicáticos nos micaxistos regionais e 2. veios de quartzo portadores de volframita e scheelita em rochas xistosas. Dados de campo, petrográücos, geoqufmicos e de inclusões fluidas são consistentes com uma origem epigenética para as mineralizações de volframita. Os fluidos mineralizantes estão intimamente associados com os processos de moscovitizaçab que ocorreram nas cúpulas dos plutões granitóides. Dados de inclusões fluidas mostram que as mineralizações de volframita foram formadas a partir de fluidos de baixa salinidade, ricos em $\mathrm{CO}_{2}$ e $\mathrm{CH}_{4}$. Nos veios de quartzo mineralizados em volframita da região de Itinga, as inclusões de $\mathrm{CO}_{2}$ apontam para temperaturas de aprisionamento na faixa de $300^{\circ} \mathrm{C}-45 \mathrm{O}^{\circ} \mathrm{C}$, a $2 \mathrm{kbar}$. A preciptação do tungstênio provavelmente ocorreu à medida que o fluido arrefecia e o pH da solução aumentava por meio da hidròlise dos minerais das rochas encaixantes e/ou por perda gradual do $\mathrm{CO}_{2}$.
\end{abstract}

Palavras-chaves: Mineralizações de tungstênio, granitóides, rochas cálcio-silicálicas, alteração hidrotermal, inclusões fluidas.

\begin{abstract}
Two tungsten mineralization types were recognized in the Middle Jequitinhonha Valley (MJV): 1. scheelite associated with calc-silicate bands in the regional micaschists and 2. wolframite and/or scheelite - bearing quartz veins in schistose rocks. Field, petrographic, geochemical and fluid inclusions data all point to an epigentetic origin for the wolframite mineralization. The mineralized fluids were closely related to muscovitization processes within the cupolas of granitoid plutons. Fluid inclusion data show mat the wolframite mineralization was formed from low salinity, $\mathrm{CO}_{2}$ and $\mathrm{CH}_{4}$ rich, aqueous fluids. In the wolframite-bearing quartz veins of Itinga region, the $\mathrm{CO}_{2}$ inclusions indicate temperatures of $300^{\circ} \mathrm{C}-450^{\circ} \mathrm{C}$ at 2 kbar. Tungsten precipitation probably took place as die fluid cooled and the $\mathrm{pH}$ of the solution increased through hydrolysis of die host-rock minerals and/or by gradual loss of $\mathrm{CO}_{2}$.
\end{abstract}

Keywords: Tungsten mineralization, granitoid, calc-silicate rocks, hydrothermal alteration, fluid inclusions.

INTRODUCTION No economic tungsten deposit is yet known in Minas Gerais. Only a few local occurrences of scheelite and or wolframite have been reported in the Quadrilátero Ferrífero (Pereira \& Santos 1984), in Galileia (Cassedanne \& Pereira 1982), in São Tiago, Nazareno and Cassiterita (Santos \& Pereira 1983). Recently a large number of occurrences has been recorded by Pedrosa-Soares et al. (1983) and Monteiro (1986) in a new metalotec in the Jequitinhonha Valley (Fig. 1). This paper records and discusses aspects of the tungsten mineralization reported in the unpublished thesis of Monteiro (1986).

The regional geological setting is that of the Araçuaí Fold Belt (Almeida 1977, Almeida et al. 1981) which was developed in the Brasiliano Cycle, 1000 to $450 \mathrm{Ma}$ ago. The belt comprises a series of NE-SW thin-skinned thrusts formed by an eastward sucession of slices of basement rocks, metasediments of the Espinhaço Supergroup, metasediments and metavolcanics of the Macaúbas Group and highly schistose rocks of the Salinas Group. The latter is host to numerous granitoid intrusions and to the tungsten mineralization. The numerous plutons in the area possibly characterize a transtension domain related to a change of direction of the Araçuaí Fold Belt, that is a major dilational zone where magma could ascend. Several types of granitoid rocks were also intruded into the migmatitic and charnockitic basement complex of the Almenara region further east.

LOCAL GEOLOGY Figure 1 displays the raltionship between the Salinas Group and the intrusive granitoid. The Salinas Group is dominated by a unit of Barrovian quartz-micaschists with varying amounts, of garnet, staurolite and hornblend. The rocks show a marked NE-NNE axial plane foliation associated with the tight isoclinal folding that accompanies the regional thrusting. Minor amounts of quartzose to arkosic quartzites and metaconglomerates are also present and skarn-like rocks occur as thin layers (rarely up to $1 \mathrm{~m}$ thick) within the micaschists (Correia-Neves et al. 1982). Not far away, in the Itinga region, the schists show clusters of andalusite and cordierite arising from an Abukuma type metamorphism (Costa et al. 1984, Costa 1987). Both the intrusives and the host schists have undergone extensive metasomatic alteration in contact zones (Pedrosa-Soares et al. 1984, Monteiro 1986). According to these authors, the regional metamorphism in the region of Coronel Murta-Salinas took place at temperatures up to $700^{\circ} \mathrm{C}$ and pressures above $3.5 \mathrm{kbar}$, indicating deeper granite emplacement than in the neighbouring Itinga lithium-bearing pegmatite field where pressures were not in excess of $2 \mathrm{~kb}$ (Costa et al. 1984). In the contact zones, the regional metamorphic rocks have been hardened during the emplacement and solidification of the granite. $\mathrm{Rb}-\mathrm{Sr}$ age determinations have yielded values of $540 \pm 10 \mathrm{Ma}$ for the Itinga granites (Sá 1977) and $525 \pm 30 \mathrm{Ma}$ for. lhe Coronel Murta biotite granite (Siga Jr. 1986). The initial ${ }^{87} \mathrm{Sr} /{ }^{86} \mathrm{Sr}$ is 0.7113 (Coronel Murta) and 0.7125 (Itinga). Rb-Sr age determination in the Araçuaí schists (Sá 1977) yielded older ages $(659 \pm 40 \mathrm{Ma})$.

THE TUNGSTEN MINERALIZATION Two types of W-mineralization were studied in the MJV province: (1) scheelite-bearing calc-silicate rocks in Rubelita, and (2) wolframite and/or scheelite-bearing quartz veins, in Itinga. The first type is widespread, being present in the thin skarn-like bands within the host schists close to the granitoid 


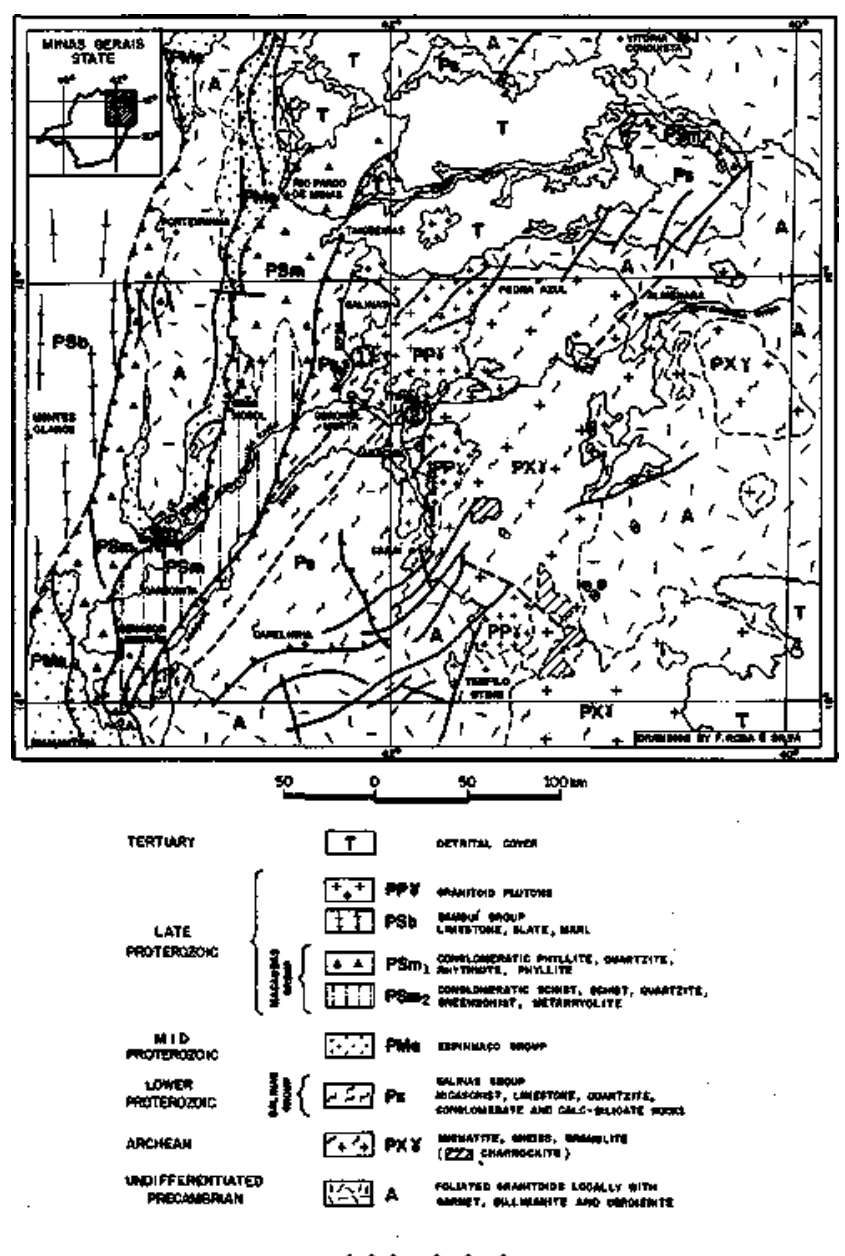

GEOEGTCLL CONTACT

Pants

Figure 1 - Geological map of Northeastern Minas Gerais and Southern Bahia (simplified and modified by Pedrosa-Soares 1984) showing the locations of the tungsten mineralizations investigated: 1. Rubelita; 2. Jenipapo

Figura 1 - Mapa geológico do nordeste de Minas Gerais e sul da Bahia (simplificado e modificado por Pedrosa-Soares 1984), mostrando a localização das mineralizações de tungstênio estudadas: 1. Rubelita; 2. Jenipapo

intrusions (Fig. 2). The mineralized quartz veins, on the other hand, are limited to an andalusite micaschist host found close to a granitoid contact at the mouth of the Jenipapo Creek on the Jequitinhonha River (Fig. 3)

The Rubelita Region In the Rubelita region (Fig. 2), mapped by Monteiro (1986), the Salinas Group is mainly formed of biotite schists with minor amounts of quartzite in the south and a metaconglomerate marker unit in the northwestern part. The biotite schists are often interlayered with minor quartz-richer bands and thin skarn-like bands of calc-silicate composition.

The schists consist of quartz, biotite, muscovite and plagioclase (oligoclase to andesine) with minor amounts of almandine, staurolite, sillimanite (fibrolitej and accessory calcite, epidote, zircon, apatite, titanite and magnetite. Tourmaline, pyrite, chlorite, sericite and muscovite nodules occur and become more frequent closer to the intrusions, as the amount of biotite (and the degree of fissility) decreases.

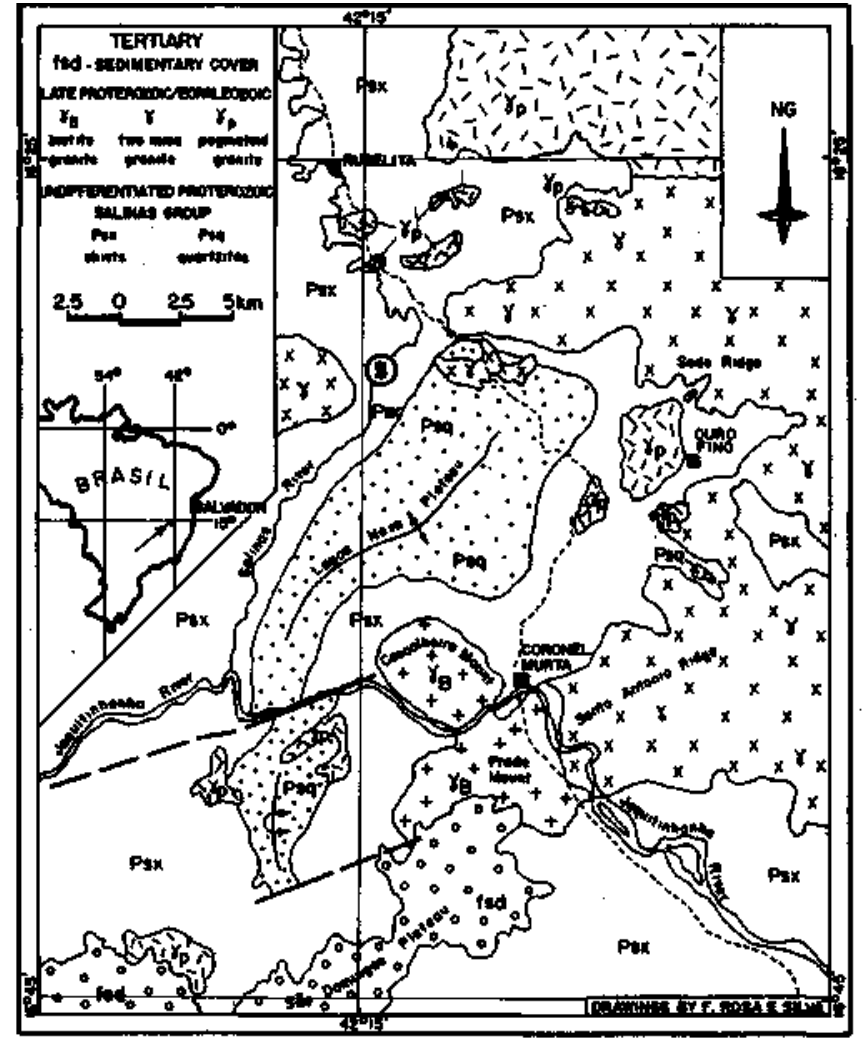

Figure 2 - Geological outline of the Coronel Murta-Rubelita region (Pedrosa-Soares 1984, Monteiro 1986), where scheelite-bearing skarns occur widespread in the host schists (Psx) close to the granitoid (y); S. main scheelite described mineralization

Figura 2 - Esboço geológico da região de Coronel Murta-Rubelita (Pedrosa-Soares 1984, Monteiro 1986), onde skarns mineralizados em scheelita ocorrem distribuídos pelos xistos hospedeiros (Psx), perto dos granitóides $(\gamma) ; 5$. principal ocorrência de scheelita descrita

Calc-silicate rocks These were divided by Monteiro (1986) into two groups: 1. one formed by dark greenish to grayish rocks with a large proportion of green amphibole and only minor pyroxene; these are often homogeneous and scheelite-free, but may form the dark border (DB) of the zoned ones (Fig. 4 and Photo 1A), and 2. other formed by lighter rocks with more pyroxene (salite) than amphibole, they are often finely banded or form the light core (LC) of the zoned ones. The last ones are restricted to the vicinities of the granitic plutons and may be mineralized with scheelite. Both types have basically the same mineralogy, varying only in the proportion of the green amphibole, piroxene, quartz, plagioclase and garnet as main constituents and epidote, sphene, apatite and zircon as accessories. Sheelite, actinolite-tremolite, clinozoisite, carbonate and pyrite belong to a late metasomatic stage which affected the light calc-silicate rocks. The plagioclase composition is higly variable, mostly in the zoned rocks and may reach even anorthitic values; albite or oligoclase are characteristic of the scheelite-bearing rocks. Microprobe analyses on the amphiboles, places them in the field of ferro-actinolites, actinolites and actinolitic hornblende while the pyroxene fall in the salite field (Costa 1987). The garnet is grossular rich and, like pyroxenes, can include all minerals except scheelite. The scheelite is only present in calc-silicate rocks having a high pyroxene/amphibole ratio, such as in the core of zoned boudins, in association with the late metasomatic paragenesis 


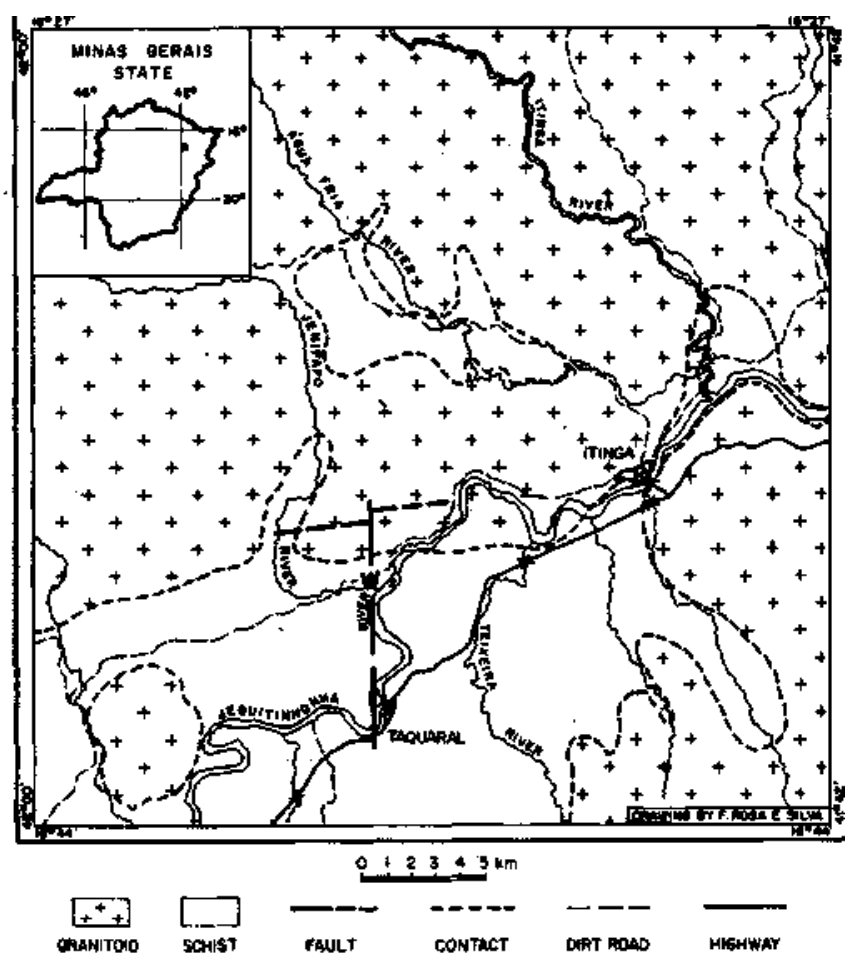

Figure 3 -Geological oulline of the Jenipapo-Itinga region (modifted from Costa et al. 1984). W- scheelite-wolframite mineralized quart veins area

Figura 3 - Eabogo geologico da reglito de Jenipapo-Itinga (modificado de Costa et al. [984). W- firea de coorrincla dos veios de quartzo mineralizadon eim scheelith e volfrumita

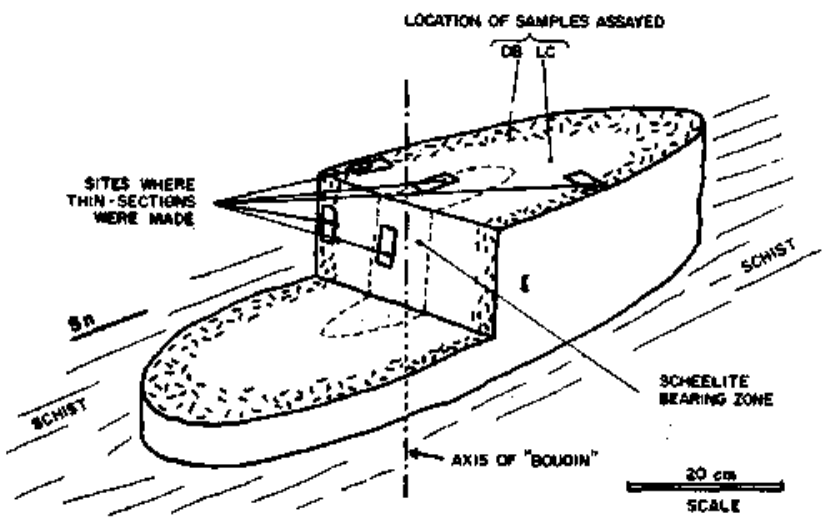

Figure 4-Outline of a mineralized boudin

Figura 4 - Esboço de um boudin mineralizado

previously described (Fig. 5, and Photos IB and 1C). The scheelite occurs throughout the light core of the zoned rocks, either as minute scattered grains or in aggregates that can reach $2.5 \mathrm{~cm}$ in size. The largest grains may often include any of the host rock minerals or may be intergrown with the grossular, stressing the late formation of both minerals. Following Korzhinskii (1970), Vidale \& Hewitt (1973) and Mehnert (1987), the zoning in the Coronel Murta-Salinas calc- silicate rocks can be explained by late metasomatic processes related to the granitoid intrusions.

The granitoid rocks These are mainly granites with only occasional granodiorites and all are intrusive into the regional
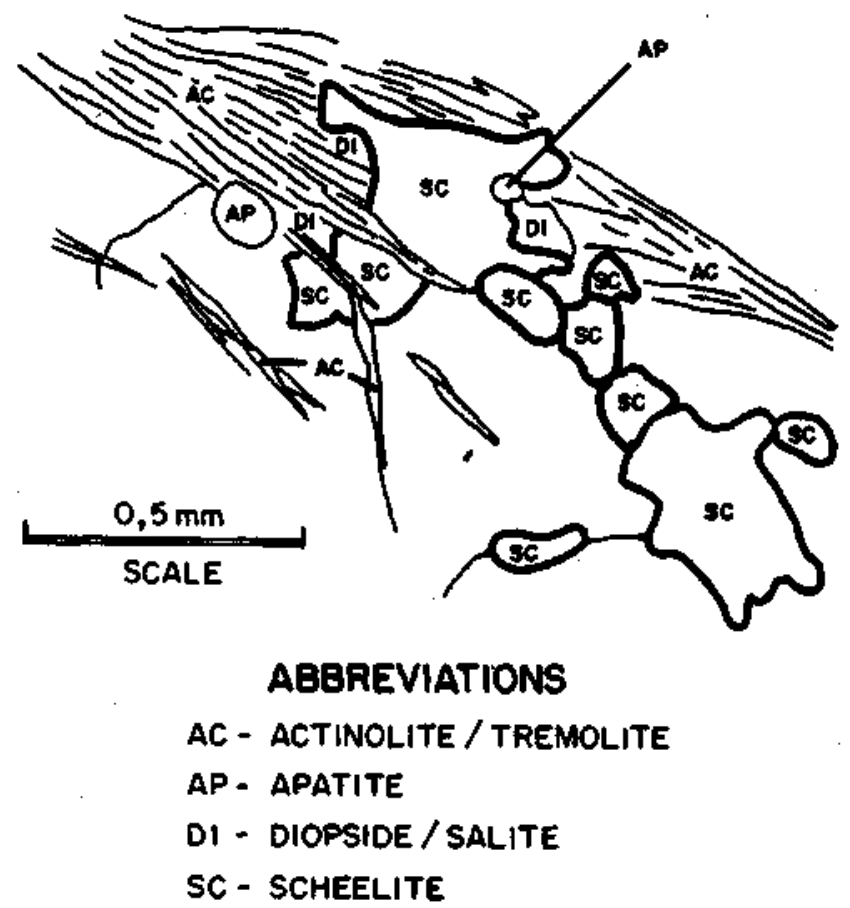

Figure 5 - Scheelite mode of occurrence (detail from Fig. 6B). Note scheelite grains in association with actinolite-tremolite needles in the light core of a zoned skarn. Actinolite-tremolite needles are cut across or terminate by scheelite grains Figura 5 - Modo de ocorrência da scheelita (pormenor da Fig. 6B). Observam-se os grãos de scheelita, em associação com as agulhas de anfíbólio, no centro claro de um boudin zonado. As agulhas de actínolita-tremolita ora cortam, ora são barradas pelos grãos de scheelita

metamorphic rocks of the Salinas Group. They are usually divided into biotite granites $\left(y_{B}\right)$, two mica granites $(\gamma)$ and pegmatoid granites $\left(\gamma_{\mathrm{P}}\right)$. Figure 2 gives the distribution of these rocks. The pegmatoid granites form the outer expression of the granitic cupolas while the two mica granites seem to represent the autometasomatic transformation of the -Ye granites, both forming the cupola facies of metasomatized granite plutons. Pegmatite dykes are widespread and have emplaced within not only the granite itself but the host schists in the neighbourhood of the intrusion (Pedrosa-Soares et al. 1987) as well. The mineralogy of both the $\gamma$ and $\gamma_{\text {в }}$ granites are very similar, differing only in the modal proportions of quartz, microcline, oligoclase, biotite, muscovite, epidote, almandine, opaques and zircon; titanite, topaz and sillimanite are less common and restricted to a few specimens. Field and petrographic relationships show that the biotite granites were intensely muscovitized along the cupolas, borders and apophyses of the intrusions. The evolutionary model for these rocks (Fig. 6) was put forward by Pedrosa-Soares (1984), Pedrosa-Soares et al. (1987) and Monteiro (1986).

The Jenipapo Region Figures 1 and 3 give the location of the only area where wolframite and scheelite-bearing quartz veins were found. The geology of this area is similar to that of Coronel Murta-Rubelita-Salinas and was described by Sá (1977) and Costa (1987). The regional metamorphism of this area seems to be of Abukuma type (Costa et al. 1984, Costa 1987). The mineralized quartz veins are a few centimeters to $1 \mathrm{~m}$ thick, the thicker veins have being mined by prospectors. The veins are hosted in cordierite-andalusite schists within a few hundred meters from the granitoid contact. Some veins have been folded and are, therefore, synchronous with a shear 

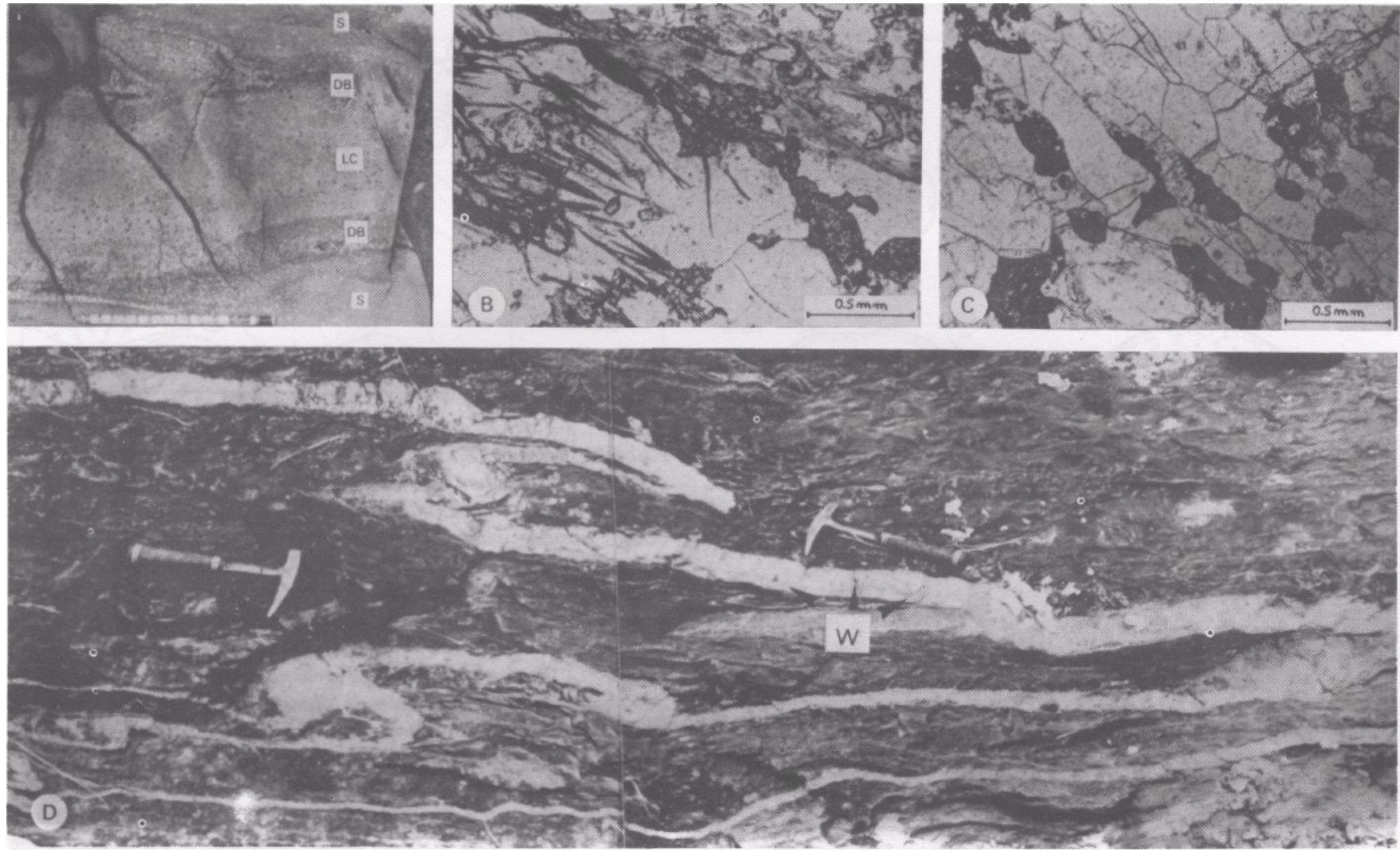

Photo $1 \mathrm{~A}$ - Zoned skarn mottled by grossular outgrowths (dark points) in the light core (LC); DB. dark border with amphibole (dark); S. white nodules of post-kinematic muscovite in micaschist. Pencil shows direction of foliation

Foto 1A - Skarn zonado mosqueado por grossulárias (pontos escuros) no centro claro (LQ; DB. borda escura com anfibólio (escuro); S. nódulos claros de moscovita pós-cinemática, no micaxisto. O lápis mostra a direção da foliação

Photo 1 B - The textural relationship between scheelite and amphibole needles (details in Fig. 5) are interpreted as indicating a late metasomatic stage for the scheelite generation

Foto $1 \mathrm{~B}$ - As relações texturais entre a scheelita e as agulhas de anfibólio (pormenores na Fig. 5) foram interpretadas como evidenciando um estágio metassomático tardio para a geração da scheelita

Photo 1C-Core of mineralized boudin viewed in section parallel to the axis of the boudin (see Fig. 4), showing mimetic orientation of scheelite grains (dark), stretching of the quartz-plagioclase matrix and replacement of plagioclase by clinozoisite (C) along fractures

Foto 1C - Núcleo de um boudin visto em corte paralelo ao seu eixo (ver Fig. 4), mostrando a orientação mimética dos grãos de scheelita (escuro), o estiramento da matriz de quartzo e plagioclásio e a substituição do plagioclásio pela clinozoisita (C) ao longo de fraturas

Photo $1 D$ - Thin quartz vein mineralized with wolframite $(W)$ and hosted by cordierite-andalusite schists, near Itinga. The vein has been folded by a shear deformation

Foto 1D - Veio de quartzo fino, mineraüzado com volframita (W) e encaixado em xisto com cordierita e andaluzita, perto de Itinga. O veio foi dobrado por uma deformação cisalhante

deformation (Photo $1 \mathrm{D})$. The veins are composed by quartz with varying amounts of wolframite, scheelite, andalusite (chiastolite) and plagioclase and do not show any evidence of zoning. Wolframite forms tabular crystals up to $7 \mathrm{~cm}$ long and has a constant ferberitic composition. The scheelite grains are also euhedral and up to $3 \mathrm{~cm}$ long, but, unlike the wolframite, they show a closed association with plagioclase clusters. The scheelite fluoresces bluish white indicating low molybdenum contents. The metamorphism paragenesis of the host rocks, with widespread andalusite and cordierite and the presence of numerous lithium pegmatites in wich the low pressure mineral petalite is particulary abundant, has been interpreted as suggesting that the granites of the Itinga region were emplaced at higher levels than those in Coronel Murta-Rubelita-Salinas region (Correia-Neves et al. 1986, 1987).

DISCUSSION AND CONCLUSIONS The following observations are consistent with an epigenetic origin for the scheelite and wolframite.

1. Systematically low $\mathrm{W}$ values $(<3 \mathrm{ppm})$ in the regional metamorphic rocks.

2. Presence of granites with anomalously high $\mathrm{W}$ values.

3. The scheelite is restricted to calc-silicate horizons under the influence of contact-metasomatic processes. 
A

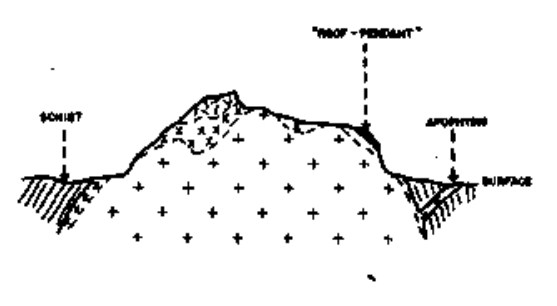

$B$
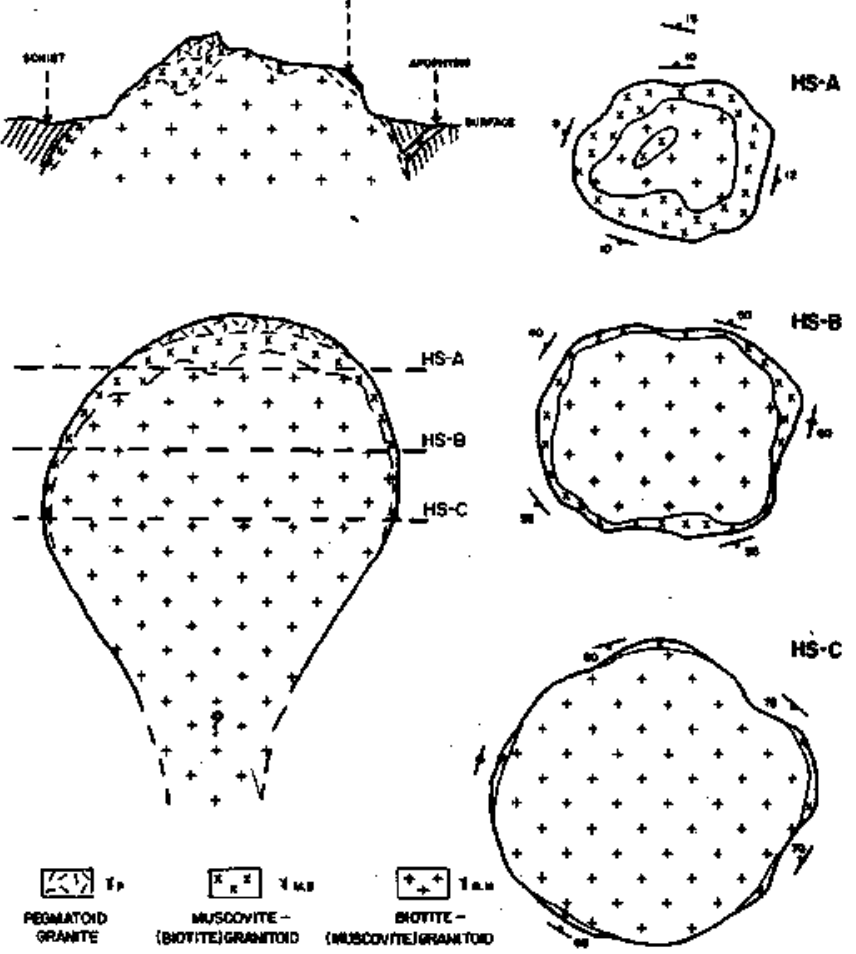

Figure 6 - Schematic outline of Coronel Murta-Rubelita granitoids. A. cross sections; B. maps of various erosion levels Figura 6 - Esboço simplificado dos granitóides da região de Coronel Murta-Rubelita. A. cortes; B. mapas de vários níveis de erosão

4. The wolframite and scheelite-bearing quartz veins are situated close to the granitoid plutons.

5. Textural relationships suggest that the scheelite was formed by the replacement of calc-silicate minerals as part of a late alteration process, related to the granite emplacement. 6. Similarities between the fluid inclusions within the $\mathrm{W}$ anomalous granitoids and those in the mineralized quartz veins.

7. The amount of scheelite in pan concentrates from drainage sediments is considerably higher close to the granitoid contact (Fig. 7).

The whereabouts of the tungsten before the granitoid emplacement is still unknown. Two main non-exclusive hypotesis are possible: 7. the $\mathrm{W}$ was incorporated into the melt during anatexis of rocks that were already enriched in that metal; 2 . the $\mathrm{W}$ entered the melt during magma ascent, either by direct assimilation of $\mathrm{W}$-enriched wall rocks or in country rock derived W-bearing fluids. Whatever the nature of the fluid incorporated by the magma and source of the tungsten, the mineralization is clearly related to the muscovitization process within and around the granitoid cupolas. Before the muscovitization the $\mathrm{W}$ was probably in the biotite flakes of the granitoid; the biotite has been widely replaced by muscovite within the cupola and the border zone. Both the processes of magmatic fractionation and metasomatic alteration would concentrate the tungsten within the newly formed muscovite. Eugster (1985) proposed mechanisms by which the $\mathrm{W}$ could be removed from earlier granitoid minerals.

Quartz fluid inclusion data from both tungsten-rich and

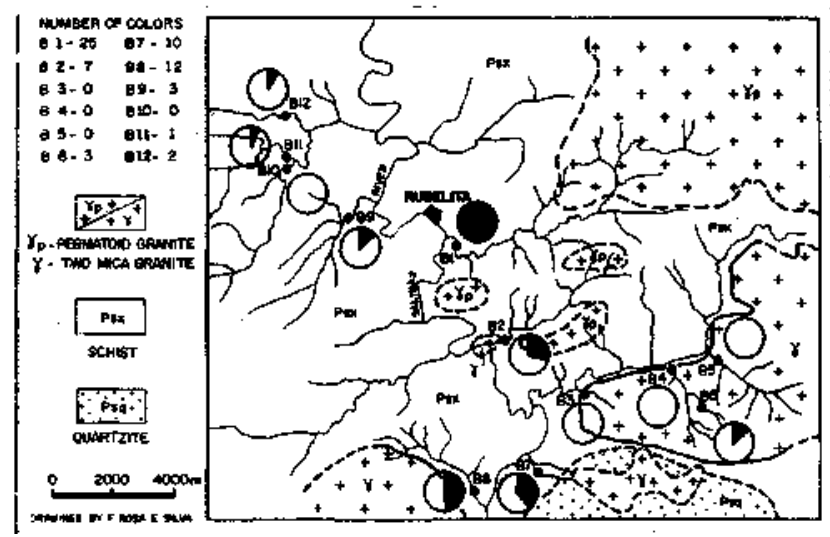

Figure 7 - Scheelite distribution from pans concentrates, Rubelita region. The number of scheelite colors (spots) are considerably higher in the drainages that cross or are close to the granitoid-schist contact: B1, B2, B7 and B8; no scheelite colors appear when drainage cross only granitoids, upstream the points B3, B4 and B5; point B6 is located downstream a large schist roof-pendant; the other points are located in drainages that cross only schistose rocks, distant from the granitoids

Figura 7 - Distribuição de scheelita em concentrados de bateia, região de Rubelita. $\mathrm{O}$ número de pintas de scheelita é consideravelmente maior nas drenagens que atravessam ou estão perto do contato xisto-granitóide: B1, B2, B7 e B8; não ocorrem pintas de scheelita quando a drenagem atravessa somente granitóides, a montante dos pontos B3, B4 e BS; o ponto B6 localiza-se a jusante de um grande roof-pendant de xisto; os outros pontos localizam-se em drenagens que cortam apenas xistos, distantes dos granitóides

tungsten-poor granitoids and from mineralized quartz veins (Monteiro 1986) as well, indicate that the $\mathrm{W}$ mineralization is related to low salinity ( $\leq 1,5 \mathrm{wt} . \% \mathrm{NaCl}$ equiv.) aqueous fluids, some of which are $\mathrm{CO}_{2}$ and $\mathrm{CH}_{4}$ rich, mainly within quartz of the mineralized veins. High $\mathrm{W}$ values correlate with $\mathrm{CO}_{2}$ and $\mathrm{CH}_{4}$ contents. Quartz fluid inclusions from tungsten-poor granitoids are nearly free of $\mathrm{CO}_{2}$ and $\mathrm{CH}_{4}$. Fluid inclusions in quartz from the granitoids were trapped at temperatures not lower than $650^{\circ} \mathrm{C}$ for pressures up to $3 \mathrm{kbar}$. For the Itinga wolframite-quartz veins the fluid inclusion data are consistent with homogenization temperatures of $300^{\circ} \mathrm{C}-450^{\circ} \mathrm{C}$ assuming pressures around $2 \mathrm{kbar}$. For that temperature interval, according to the experimental and thermodynamic data of Halley (1982), the tungsten transport should have been in the form of either $\mathrm{HWO}_{4}$ or $\mathrm{WO}_{4}$ as has been suggested by Krauskopf (1970) and confirmed by Wesolowsky et al. (1982) for slightly acid or slightly alkaline solutions. The presence of $\mathrm{CH}_{4}^{-}$and $\mathrm{CO}_{2}^{-}$rich fluid inclusions in beryls from the pegmatites of the region, as demonstrated by Correia-Neves et al. (1984), reinforces the hypothesis that both the pegmatites and the mineralized quartz veins are geneticaly linked to the late stages of the magmatic and metasomatic evolution of the granites. The association between tungsten deposits and $\mathrm{CO}_{2}$ and $\mathrm{CH}_{4}$ fluids is common in a variety of geological environments (Pokalov et al. 1979, Higgins 1980, Higgins 1985, Youngle \& Wen 1982, Giuliani 1985). Most of these authors stressed the role of $\mathrm{CO}_{2}$ in the $\mathrm{W}$ deposition.

According to Krauskopf (1970) wolframite and scheelite deposition is favoured by a $\mathrm{pH}$ increase of the fluid. Higgins (1985) showed that an increase of only one in the $\mathrm{pH}$ value of the solution, due to a progressive loss of $\mathrm{CO}_{2}$ either by immiscibility or retrograde boiling, would significantly reduce 
the tungsten solubility thereby causing the precipitation of the metal. Because of the very low solubilities of wolframites, Eugster (1985) remarked that $\mathrm{H}_{2} \mathrm{WO}_{4}, \mathrm{FeCl}_{2}$ or $\mathrm{MnCl}_{2}$ solutes should not coexist in solution, hence if the $\mathrm{H}_{2} \mathrm{WO}_{4}$ was derived from, the hydrothermal fluids that came from the granitoids, then the chlorides of iron and/or manganese could have come from the wall rocks, that is, from the ilmenite-rich biotite schistes. In our specific situation, whenever the $\mathrm{FeCl}_{2}$ exceeded the solubility product of the ferberite, deposition took place. The scheelite formation, on the other hand, probably occured in more alkaline environments where calcium was available. The presence of calcic plagioclase in the veins would explain not only the scheelite precipitation but its association with ferberite. In the calc-silicate rocks, the scheelite association typically with sodic plagioclase amid more calcic members, could be explained by the liberation of calcium from some plagioclase during the late hydrothermal alteration that affected the granitoid contact zone. Einaudi et al. (1981), for instance, have shown that very high tungsten grades are invariably associated with retrograde mineral assemblages.

Figure 8 summarizes our model for the genesis of tungsten mineralization in the $M J V$. This fits well with that know as two-stage epigenetic model, and the concordant replacement type deposit in the classification recently proposed by Cheifletz (1988) for stratiform tungsten mineralization. While at first sight the MJV metallotect seem distinct from that of the well known Borborema Scheelite Province, in Northeastern Brazil, for wich a syngenetic volcanosedimentary model has been widely postulated (Salim et al. 1979), the data in the pioneer studies of Johnston \& Vasconceflos $(1943,1945)$ and those of Maranhão (1971) and Barbosa et al. (1986) are also consistent with an epigenetic model such is presented here. It is also worthy of mention that the Borborema metallotects are both the sites of widespread gold mineralization. Preliminary information suggest that although the gold might also be linked to the hydrothermal solutions related to similar calc-alkaline granite intrusions, its deposition clearly took place at much lower temperatures than scheelite, being apparently restricted to the shear zone environments of thrust structures.

Acknowledgements We are grateful to Frederico Rosa e Silva for their part in drafting some figures, to Eber Faioli for the half-tone reproductions and to Rosi Carvalho Lemos for the typing of the manuscript. This study was supported by CNPq, FINEP and UFMG.

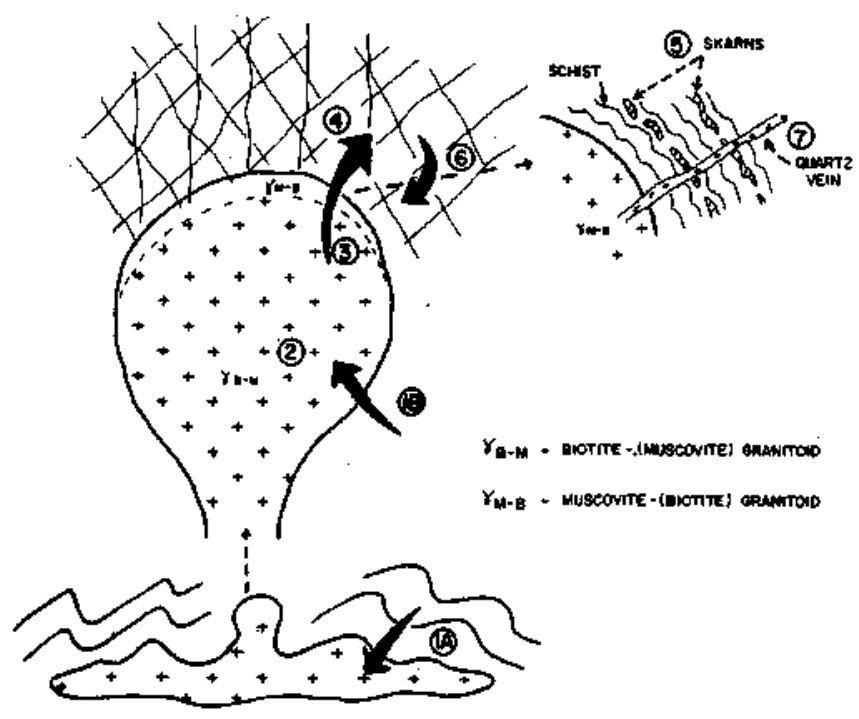

Figure 8-Model for tungsten mineralization in the Middle Jequitinhonha Valley. 1. Introduction of $W ; \mathbf{1 A}$. from crustal remelting; 1B. from country rocks; 2 . disseminated $W$ incorporated into micas; 3. $W$ enrichment during muscovitization in the granite cupola; 4. W transportation as acid complexes in hydrothermal fluid; $\mathbf{5}$. deposition of scheelite in skarn as pH increases and calcium is liberated; 6. loss of $\mathrm{CO}_{2}$ of the hydrothermal fluid and wolframite precipitation in quartz veins; 7. Ca-plagioclase in quartz veins supplys $C$ a for scheelite deposition with wolframite

Figura 8 - Modelo da mineralização de tungstênio no médio Vale de Jequitinhonha. 1. introdução do W; 1A. a partir da fusão crustal; 1B. das rochas encaixantes; $\mathbf{2}$. W disseminado está incorporado nas micas; $\mathbf{3}$. enriquecimento do $\mathrm{W}$, durante a moscovitização, nas cúpulas granitóides; 4. transporte do $\mathrm{W}$ como complexos ácidos, pelo fluido hidrotermal; 5. formação da scheelita nos skarns, à medida que o $\mathrm{pH}$ aumenta e o cálcio é liberado; 6 . perda de $\mathrm{CO}_{2}$ do fluido hidrotermal e formação da volframita nos veios de quartzo; 7. plagioclásio cálcico, nos veios de quartzo, fornece o Ca para a precipitação da scheelita junto com a volframita

\section{REFERENCES}

ALMEIDA, F.F.M de. 1977. O Cráton do São Francisco. Rev. Bras. Geoc., 7(4):349-364

ALMEIDÄ, F.F.M de; HASUI, Y.; BRITO NEVES, B.B. de; FUCK R. A. 1981. Brasilian structural provinces: an introduction. Earth Science Rev. 17:1-29

BARBOSA, F.L.M.; DE MELLO, A.A.; MARANHÃO, RJ.L. 1986. Tungsten Mineralization of Brazil. Earth Science Rev., 18:201-208. (IGCP Project, 26)

CASSEDANNE, JP.; PEREIRA, R.M 1982. Découverte de la scheelite dans la Province Pégmatique Orientale Brésilienne. AnAcad.bras.Cienc., 54(2):413-417.

CHEILLETZ, A. 1988. Stratiform tungsten deposits: a review (with implications for the Yxsjöberg-Sandudden deposits of Sweden) Geologie en Mijnbouw, 67:293-3.11.

CORREIA NEVES, J.M.; QUEMENEUR J.J.G.; BARAUD, R PEDROSA SOARES A.C.; MONTEIRO, R.L.B.P.; SCLIAR.C. 1982. Avaliação das Provincias pegmatíticas de Minas Gerais. I Enquadramento Geológico. FINEP/UFMG. 227p (Relatório Final) (Unpubl.).

CORREIA NEVES, J.M.; DUTRA, C.V.; MONTEIRO, R.L.B.P. 1984. Composição química de berilos pegmatíticos do Brasil e seu significado petrológico e metalogenético. Rev. Bras. Geoc., 14(3): 137-146.

CORREIA NEVES, JM • PEDROSA SOARES, A.C. MARCIANO, V.R.P.R.O. 1986. Província Pegmatítica Oriental do Brasil à luz dos conhecimentos atuais. Rev. Bras. Geoc., 16(1): 106-118.
CORREIA NEVES, J.M.; PEDROSA SOARES, A.C.; MARCIANO, V.R.P.R.O.; MONTEIRO R.L.B.P.; FERNANDES, M.L.S. 1987. Granitoids and pegmatites from the northern section of the Eastern Brazilian Pegmatite Province. In: ISGAM, Salvador, 1987. Excursion Guides.. Salvador p. 125-144.

COSTA, A.G. 1987. Petrologie und geochemische Untersuchungen des Gneis-Migmatite-Gebiets von Itinga, Jequitinhonha-Tal, Nordoestliches Minas Gerais, Brasilien. West Germany. 288p. (Dr. Thesis, TU-Clausthal).

COSTA, A.G.; CORREIRA, J.M.; MUELLER, G. 1984. Feições polimetamórficas dos metapelitos da regiẫo de Itinga, Minas Gerais. In: CONGR.BRAS.GEOL., 33. Rio de Janeiro, 1984. Anais... Rio de Janeiro, SBG. v.7, p. 3166-3180.

EINAUDI, M.T.; MEINERT, L.D.; NEWBERRY, RJ. 1981 Skarn deposits. Econ. Geol. 75:317-391.

EUGSTER, H.P. 1985. Granites and hydrothermal ore deposits: a geological framework. Mineral Mag., 49:1-23.

GIULIANI, G. 1985. Le gisement de tungstène de Xihuashan (Sud-Jiangxi-Chine): relations granites, alterations deuteriques-hydrothermales, mineralisations. Mineral. Deposita, 20:107-115.

HALLEY, S. 1982. Solubility of the tungstate minerals. University Tasmania. 91p. (B.Sc. Honors Rept.)

HIGGINS, N.C. 1980. Fluid inclusion evidence for the transport of tungsten by carbonate complexes in hydrothermal solutions. Canadian Jour. Earth Sci. 17:823-830. 
HIGGINS, N.C. 1985. Wolframite deposition in a hydrothennal vein system: the Grey River tungsten prospect, Newfoundland, Canada. Econ.Geol.., 80:1297-1327.

JOHNSTON JR., W.D.; VASCONCELOS, P.M. 1943. Tungstênio na Paraíba e Rio Grande do Norte. Min. Metal., 41:247-260.

JOHNSTON JR., W.D.; VASCONCELLOS, P.M. 1945. Scheelite in northeastern Brazil.Econ.Geol.,4fo34-5Q.

KORZHINSKII, D.S. 1970. Theory of metasomatic zoning. (Jean Agrell, Transi.), New York, Oxford Clarendon Press. 162p.

KRAUSKOPF, K.B. 1970. Tungsten (Wolfram). In: WEDEPOHL, K.H. ed. Handbook of geochemistry. Berlim-Heidelberg-New York, Springer. vol. II (74).

MARANHÂA, RJ.L. 1971 Geologia econômica das ocorrências de Bonfim, Gupiara e Olho D'Água do Teixeira, no distrito tungstenífero de Lages-RN. In: SIMP.GEOL.NE, 5, Recife, 19n.Bol.Esp... SBG/NE. v.1, p.53-64.

MEHNERT, K.R. 1987. The granitízatíon problem-revisited. Fortschritte der Mineralogie, 65:285-306.

MONTEIRO, R.L.B.P. 1986. As mineralizaçôes de tungstênio no médio vale do Jequitinhonha, NE de Minas Gerais, Brasil. Brasília. 236p. (Dissertação de Mestrado, Universidade de Brasília).

PEDROSA-SOARES, A.C. 1984. Metamorfismo, granitogênese e mineralizações associadas na região de Coronel Muría, NE de Minas Gerais, Brasil. Brasília. 171p. (Dissertação de Mestrado, Universidade de Brasília)

PEDROSA-SOARES, A.C.; COSTA, A.G.; CORREIA NEVES, J.M. 1983. A mineralização de scheelita nas rochas calcossilicáticas no médio Jequitinhonha, MG. In: SIMP.GEOL.MG, 2., Belo Horizonte, 1983. Anais... Belo Horizonte, SBG/MG. v.3, p.297-305.

PEDROSA-SOARES, A.C.; LEONARDOS, O.H.; CORREIA NEVES, J.M. 1984. Aspectos metamórficos de seqüências supracrustais da Faixa Araçuaí em Minas Gerais. In: CONGR.BRAS.GEOL., 33. Rio de Janeiro, 1984. Anais... Rio de Janeiro, SBG. v.7, p.3056-3065.

PEDROSA-SOARES, A.C.; MONTEIRO, R.L.B.P.; CORREIA NEVES, J.M.; LEONARDOS, O.H.; FUZIKAWA, K. 1987. Metasomatic evolution of granites, Northeast Minas Gerais, Brazil. RevJSras.Geoc., 17(4):512-518. (erratum of the tables published in RevMras.Geoc., 18(3):319).

PEREIRA, R.M.; SANTOS, R.A. dos 1984. A ocorrência de scheelita estratiforme de Caeté, MG: base de uma nova interpretação metalogenética para os índices de $\mathrm{W}, \mathrm{Sb}$ e $\mathrm{Hg}$ do Quadrílatero Ferrifero. Min. metal.,450:38-42.

POKALOV, V.T.; VOLOKHONSTSEVA, S.V.; VASIN, V.V. 1979. Thermobarogeochemical conditions for the formation and the stage nature of the Malyi Oinogo tungsten-molybdenum deposit. In: KUZNETSOV, V.A. ed. Major parameters of natural processes of endogenetic ore formation (in Russian), v.1, p.252-259. (English abstract in: Fluid inclusion Research, Proceedings of COFFI, 12:143).

S A, J.H. da S. 1977. Pegmatitos litiníferos da região de Itinga-Araçuaí, Minas Gerais. São Paulo. 112p. (Tese de Doutorado, Universidade de São Paulo).

SALIM, J.; LEGRAND, J.M.; DARDENNE, M.A. 1979. Controles géologiques et gênese dês mineralisations de tungstène de Ia province scheelitifère précambrienne du NE du Brésil. In: CONGR.GEOL.INT., 26. Paris, 1979. Abstracts...París. v.3, 13-20:1004.

SANTOS, R.A.; PEREIRA, R.M. 1983. Nota sobre a ocorrência de scheelita na região de São Tiago, Nazareno e Cassiterita, MG. MinMetal., 444:32-33.

SIGA JR., O. 1986. A evolução geotectônica da porção nordeste de Minas Gerais, com base em interpretações geocronológicas. São Paulo. 140p. (Dissertação de Mestrado, Universidade de São Paulo).

VIDALE, R.; HEWITT, D.W. 1973 "Mobile" components in the formation of calc-silicate bands. AmMineralogist, 58:991-997.

WELOLOWSKI, D.; DRUMMOND, S.E.; MESMER, R.E.; OHMOTO, H. 1982. Tungsten speciation in $\mathrm{NaCl}$ solutions to $300^{\circ} \mathrm{C}$ (abs.). Geol.Soc America Abstracts with Programs. 14:645.

YOUNGLE, W.; WEN, M.Y. 1982. Multi-phase intrusion and multi-phase mineralization in Xihuasham tungsten ore fields. Symposium sponsored by ESCAP/RMRDC and Ministry of Geology. Bandung, Indonesia and Beijin, China. Editors: Tungsten Geology. Jiangxi, China. 584p. 